\title{
【症例報告】
}

\section{Coix-seed Reactive Derivatives(CRD) 摂取が難治性貨幣 状湿疹の改善に有用であった事例報告 Successful Treatment of Severe Nummular Eczema of Fingers with Coix-seed Reactive Derivatives (CRD): A Case Report}

\author{
鈴木信孝 ${ }^{1, *}$, 橋本慎太郎 ${ }^{2}$, 許 鳳浩 ${ }^{1,3}$, 上馬塲和夫 ${ }^{3,4}$ \\ Nobutaka SUZUKI ${ }^{1,}$, Shintaro HASHIMOTO ${ }^{2}$, Hoko KYO ${ }^{1,3}$, Kazuo UEBABA ${ }^{3,4}$ \\ ${ }^{1}$ 金沢大学大学院医薬保健学総合研究科 臨床研究開発補完代替医療学講座 \\ 2 大名町スキンクリニック \\ ${ }^{3}$ 医療法人ホスピィー・浦田クリニック \\ ${ }^{4}$ 帝京平成大学
}

【要 旨】

ハトムギの外殼・薄皮・渋皮を含む全粒 熱水抽出エキス(Coix-seed Reactive Derivatives;CRD) 摂取が有用であった両手 指の難治性貨幣状湿疹の 1 例を経験したの で報告した。患者は 52 歳, 女性. 2012 年 3 月に湿疹が多数出現し, 全身に広がった. 貨幣状湿疹の診断のもとにステロイド軟膏と 抗ヒスタミン薬の内服を受けるも，好転しな いため, 発症から 3 年目の 2015 年に薬を 中止した. 2017 年 10 月から CRD 1 包 あたり $2.2 \mathrm{~g}$ 含有する栄養補助食品を 1 日 当たり 2 包摂取し始めたところ, 急速に病 変は改善し始め, 摂取 1 ヶ月目には完治し, 現在に至っている。本例は, 発症から 5 年 半という長期にわたって, とくに両手指に発 疹と強い掻痒感が続いていたが, CRD 摂取 により, 約 1 ヶ月という短期間に根治をみた 例である.

【キーワード】

ハトムギ，CRD，ハトムギ反応生成物，貨 幣状湿疹
はじめに

ハトムギの外殼・薄皮・渋皮を含む全粒熱水抽出エキ ス (Coix-seed Reactive Derivatives;CRD) 摂取が有用で あった難治性貨幣状湿疹の 1 例を経験したので報告した。

症例

患者は, 女性で, 既往歴として子供の頃からアレルギー 体質を有し，鼻炎や薬疹を認めていた３5 歳の時，顔や 躯幹を中心にアトピー性皮膚炎を発症し，3 年間で治癒 した。その際, 霊芝も摂取していたという。2012 年 3 月, 52 歳の時，慰部を中心に赤く丸い皮疹が数多く出現。そ の後同年 7 月に皮疹は足から背部，両手，顔，頭皮へと 全身に広がった。発症時の皮疹は丘疹が集簇し，表面に は鱗屑を伴い，強い掻痒感を認めたという（Fig.1）。

近医を受診したところ，全身性の貨幣状湿疹と診断さ れ，0.05％アンテベート軟膏 (ベタメタゾン酪酸エステ ルプロピオン酸エステル), プロペト軟膏（白色ワセリン） と抗ヒスタミン剤のアレグラ錠 $60 \mathrm{mg}$ (フェキソフェナ ジン塩酸塩）を 1 日 2 回処方された。しかし，あまり効 果がなかったため，別の皮膚科を受診し，同様な薬を処 方された。約 1 年間は医師の指示通り毎日ステロイド剤 の塗布と内服薬を使用していたが，2 年目からは痒くて 我慢できない時のみ，2〜3 日間薬を使用した。内服薬 で痒みは若干軽減したものの, 湿疹が治まることはなかっ た。その頃から，霊芝を摂取し始めたところ，両手以外 の皮疹は軽快した。 3 年目以降は霊芝に加えプラセンタ

受理日：2019 年 2 月 20 日

* 干 920-8640＼cjkstart石川県金沢市宝町 13-1Ｔel: 076-265-2147Ｆax: 076-234-4247Ｅ-mail: pcam@med.kanazawa-u.ac.jp 


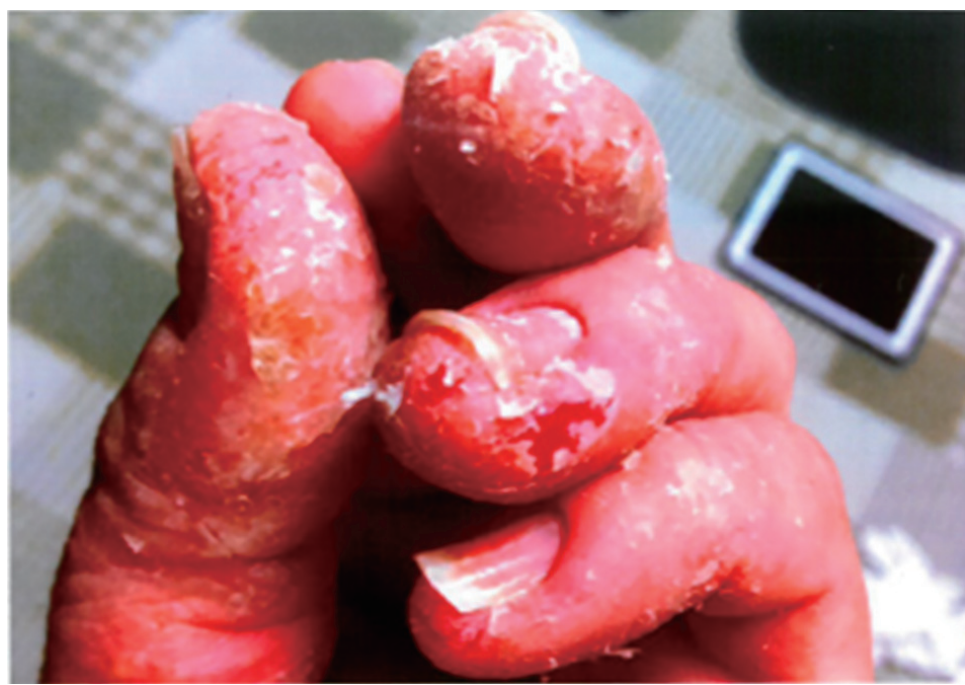

Fig. 1 Eczema of left hand at the age of 52
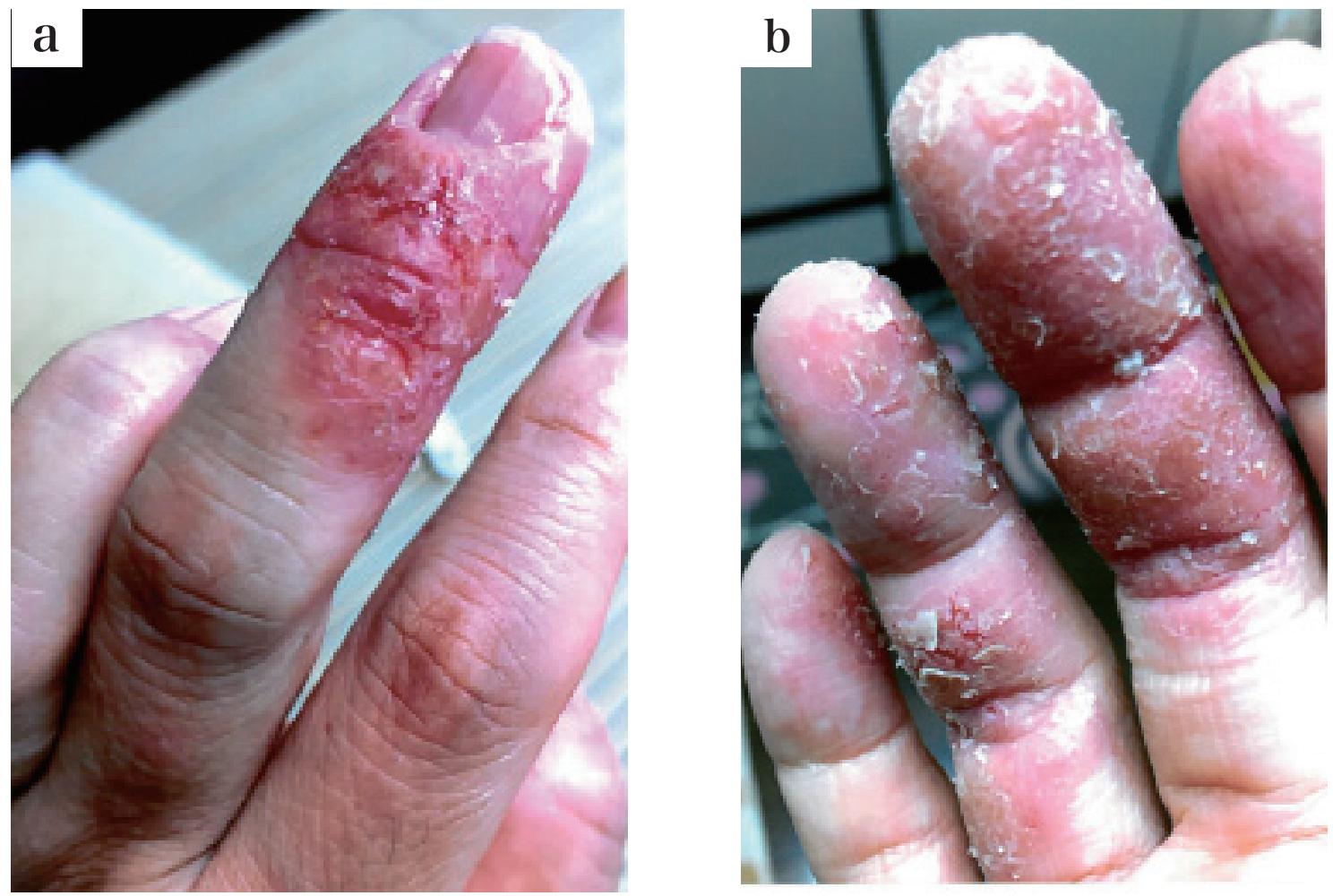

Fig. 2 Eczema of hands at the age of 56 $\mathrm{a}$ : left hand $\mathrm{b}$ : right hand

エキスを摂取し始め，薬は一切使用せずに経過をみていた。 しかし，両手指の湿疹局面だけは，増悪を繰り返し，改 善することは無く, 強い掻痒感などで大変苦しい思いをし ていたという (Fig.2)。ハトムギは肌に良いと考え，霊芝と プラセンタエキスは中止し, 2017 年 10 月（57 歳）から 1 包あたり CRD を $2.2 \mathrm{~g}$ 含有する栄養補助食品（大木産業 株式会社製）を夕食後 1 包，就寝 30 分前に 1 包の計 2 包 の摂取を開始した (Fig.3). CRD 摂取 2 ヶ月過ぎには，皮 膚の掻痒感のみならず，湿疹も消失した。摂取 6 ヶ月目か
らは就寝前に 1 包だけを摂取し, 現在に至っている (Fig.4)。 2019 年 2 月現在, 湿疹の再発はない.

\section{考 察}

著者らは，CRD 摂取が難治性の皮膚疾患に有効であつ た例をこれまでいくつか報告している。たとえば,アトピー 性皮膚炎/発症から約 4 年 $\rightarrow$ 摂取から 4 个月で完治 ${ }^{1)}$, 皮 膚亀裂を伴う手湿疹／発症から約 15 年 $\rightarrow$ 摂取から 3 个月 

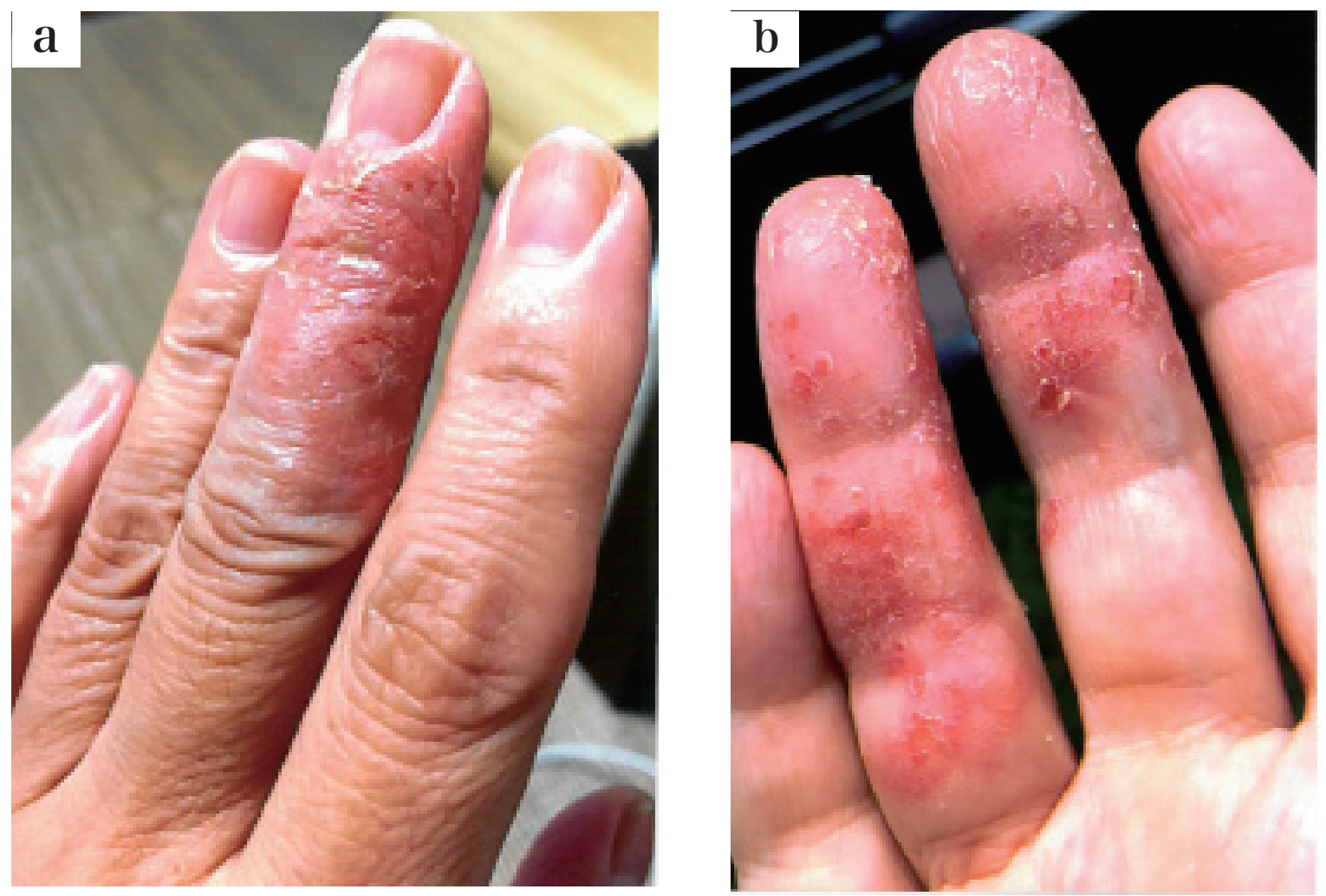

Fig. 3 Eczema of hands at the age of 57

$\mathrm{a}$ : left hand $\mathrm{b}$ : right hand

These photographs were taken just before CRD (Coix-seed Reactive Derivatives) intake.
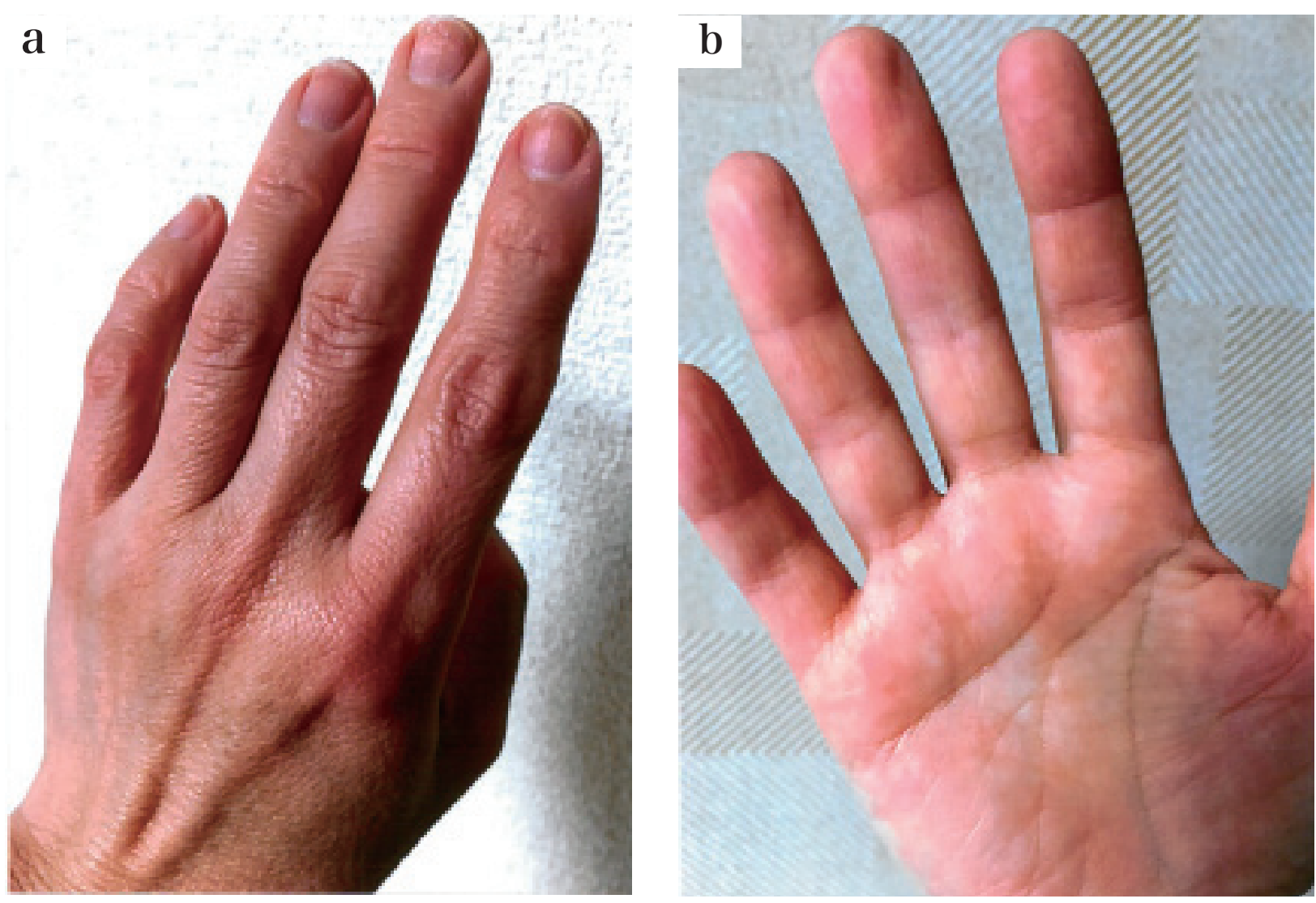

Fig. 4 Both hands at the age of 58

$a$ : left hand $b$ : right hand

These photographs were taken after 1 year of CRD intake.

※ CRD 4.4g/day for the first 6 months and CRD 2.2g/day for the next 6 months. 
で完治 ${ }^{1)}$, 掌蹠膿疮症 / 発症から約 2 年 $\rightarrow$ 摂取から 2 个月 で著明改善 ${ }^{1)}$, 接触性皮膚炎/発症から約 20 年 $\rightarrow$ 摂取か ら 6 週間で完治 ${ }^{1)}$, 尋常性痤瘡/発症から 3 年 $\rightarrow$ 摂取から 3 ケ月で著明改善 ${ }^{1)}$, 摩擦性黑皮症/発症から 20 年 $\rightarrow$ 摂取 から 3 个月で著明改善 (in press), 皮膚の光老化によるしわ・ 色素沈着/発症から 10 年 摂取から 3 ケ月で著明改善 (in press), 足底疮贅 / 発症から 1 年 6 ケ月 $\rightarrow$ 摂取から 4 个月 で完治 ${ }^{2)}$ などとなっており, 本例の貨幣状湿疹も発症から 5 年半 $\rightarrow$ 摂取から 2 ケ月後には完治している。 また，いず れの例も西洋現代医学の治療に抵抗した症例であった。

CRDの作用機序としては，たとえば (1) Th1/Th2 の免 疫バランスを Th1 優位に導きTh2 を抑える ${ }^{3)}$, (2) 様々な 抗炎症, 抗酸化物質を有する ${ }^{4)}$, (3) 皮膚の線維芽細胞を増 やしコラーゲン産生を促す (投稿準備中), (4) 抗菌作用 ${ }^{5)}$, (5) 皮膚上皮の増殖を促す（投稿準備中）などが挙げられる が, むしろ中医学的な考方方をすれば, 皮膚のターンオー バーを促し，皮膚の上皮のみならず真皮にも働きかけ，い わゆる健常な皮膚を作る作用を有していると考えるのが適 当かもしれない，事実，皮膚ターンオーバーが速い疾患で ある尋常性乾癬 5 例の観察では, CRD 撕取が有効であっ た例はなかった (未発表)。

貨幣状湿疹は，本例のように病変が悪化し，散布疹を生 じ，自家感作性皮膚炎に移行することも少なくない ${ }^{6)}$. 病 因としては，虫刺症から移行する例や，接触性皮膚炎から 移行する例, また高齢者では皮脂欠乏性湿疹に続発する例 も多く，アトピー性皮膚炎の一症状として出現することも ある ${ }^{6)}$. 治療としては通常, ステロイド剤の外用と抗ヒス タミン剂の内服を行う。

本例では，患者が皮膚科治療を中止したため，CRD の 直接作用を観察することができたが，著者らは原則，通常 医療を補完する形での CRD 摂取を推奨している。とくに, アトピー性皮膚炎の場合などは，CRD を併用することによ りステロイドの離脱が容易になった例も多く経験している (未発表)。いずれにしろ, 難治性皮膚疾患の場合, CRD を併用することは, 有益な方法の一つとなるかもしれない.

まとめ

難治性貨幣状湿疹に CRD が有用な例を報告した. 本ケー スは，他の治療を並行して行っていなかったので，当該食 品の直接作用を知る上でも大変貴重な症例であったと思わ れた。

\section{助成元}

なし
者鈴木信孝らが設立した大学発ベンチャー企業（株）CRD の研究開発食品である.

\section{参考文献}

1) 鈴木信孝, 許鳳浩. 八トムギ全粒熱水抽出エキス: 事例研究. 日本補完代替医療学会誌. 2018; 15(2): 127-132.

2) 鈴木信孝, 川島拓也, 許鳳浩ら. Coix-seed Reactive Derivatives (CRD) とビタミン剂の併用療法により根治した 難治性疮贅・コンジローマ症例 . 日本補完代替医療学会誌. 2018; 15(2): 133-139.

3) 鈴木信孝, 許鳳浩, 上馬塲和夫. Coix-seed Reactive Derivatives (CRD) の Th1/Th2 バランスに与える影響. 日 本補完代替医療学会誌. 2018; 15(2): 113-116.

4) 鈴木里芳, 徳田春邦, 鈴木信孝ら. ハトムギの抗腫瘍なら びに抗炎症作用に関する検討. 日本補完代替医療学会誌. 2013; 10(2): 75-85.

5) 鈴木信孝．ハトムギと健康体質．FOOD STYLE 21．2014; 18(6): 57-61.

6) 清水宏。あたらしい皮膚科学。第 3 版。東京. 中山書店. 2018: 125.

\section{利益相反}

本試験に用いたハトムギ全粒熱水抽出エキス CRD は著 


\author{
ABSTRACT \\ Successful Treatment of Severe Nummular Eczema of Fingers \\ with Coix-seed Reactive Derivatives (CRD): A Case Report \\ Nobutaka SUZUKI ${ }^{1}$, Shintaro HASHIMOTO ${ }^{2}$, Hoko KYO ${ }^{1,3}$, Kazuo UEBABA ${ }^{3,4}$ \\ ${ }^{1}$ Department of Complementary and Alternative Medicine Clinical Research and Development, \\ Kanazawa University Graduate School of Medical Science \\ ${ }^{2}$ Daimyomachi skin Clinic \\ ${ }^{3}$ Urata Clinic, Hospy Medical Association \\ ${ }^{4}$ Teikyo Heisei University
}

In this report, we presented the case of a 52-year-old woman who developed intractable nummular eczema of fingers for over 5 years. Coix-seed Reactive Derivatives(CRD) was administrated orally $2.2 \mathrm{~g}$ twice a day for 6 months. The lesions cured markedly within one month. Although CRD intake seemed to be effective in this case, further studies are needed to define the optimal dose of this food.

Key words: Coix lacryma-jobi L. var. ma-yuen Stapf, CRD, Coix-seed reactive derivatives, nummular eczema 